\title{
Double evidential morphology in Turkish
}

\author{
Eszter Ótott-Kovács*
}

\begin{abstract}
Turkish and Bulgarian both have "double evidential" constructions, which seem to contain reiterated evidential morphemes. This paper, focusing on Turkish data, shows that despite the morphological similarity between the indirect evidential $-m I S ̧$ and the "second" - $m I S \zeta$, double evidentials are not an instance of reduplication. Instead, I propose based on morphological evidence (separability of suffixes, morphological spell-out of related Turkic languages) and semantic evidence (the "second" $-m I S$ introduces a new indexical, the Evaluator) that the second $-m I s$ is the spell-out of a distinct syntactic head, which I call Dubitative.
\end{abstract}

Keywords. evidentiality; speaker commitment; dubitative; double evidentials; Turkish; Bulgarian

1. Introduction. Turkish is a language with grammatically marked evidentials (Izvorski 1997, Şener 2011, Meriçli 2016). Evidentials encode the source of information (Aikhenvald 2004). The Turkish suffixes in $-m I s ̧$ and $-(y) m I s ̧$ express that the event was not directly witnessed by the speaker (hence the term 'indirect evidentials'), rather the speaker heard about it from someone else, or made an inference about it based on some evidence. (1) and (2) offer illustrative examples for such reportative and inferential evidentials.

(1) I find one of my chickens dead. Later I talk to my neighbor who says that the chicken was killed by a fox.

Tavuk-lar-dan birin-i tilki boğ-muş. chicken-PL-ABL one-ACC fox strangle-3SG.EVID ${ }^{1}$

'A fox killed one of the chickens (I heard). ${ }^{2}$
$\checkmark$ I don't believe this.
$\checkmark$ This is not true.
$\checkmark$ I believe this.

(2) Shortly after I find one my chickens dead, I see a fox, so I conclude that my chicken was killed by a fox.

Tavuk-lar-dan birin-i tilki boğ-muş.

chicken-PL-ABL one-ACC fox strangle-3SG.EVID

'A fox killed one of the chickens (I infer).'

\# I don't believe this. $\quad$ \# This is not true. $\quad \checkmark$ I believe this.

A core property of indirect evidentials is that they can weaken the speaker's commitment to the scope proposition, which is 'the fox killed the chicken' in (1) (Faller 2002, Murray 2010,

\footnotetext{
${ }^{*}$ I am grateful for my consultants for their time and effort that they devoted to answer my questions. I am deeply indebted to Figen Uç for the discussion on the Turkish examples. I would also like to thank Sarah Murray, Lingzi Zhuang, Ekaterina Georgieva and the members of the Cornell Interdisciplinary Semantics Research Group for their comments and suggestions. All errors are mine.

Author: Eszter Ótott-Kovács, Cornell University (eo264@cornell.edu).

${ }^{1}$ Glosses: $\mathrm{ABL}=$ ablative, $\mathrm{ACC}=$ accusative, $\mathrm{DAT}=$ dative, $\mathrm{DUB}=$ dubitative, $\mathrm{EVID}=$ indirect evidential, $\mathrm{GEN}=$ genitive, $\mathrm{LOC}=$ locative, $\mathrm{LV}=$ light verb, $\mathrm{PASS}=$ passive, $\mathrm{PL}=$ plural, $\mathrm{POSS}=$ possessive, $\mathrm{PROSP}=$ prospective, $\mathrm{PST}=$ past, $\mathrm{SG}=$ singular.

${ }^{2}$ The fox-sentences are adapted from Faller 2002.
} 
2017). That is, the speaker does not have to be committed to the truth of the scope proposition of an indirect evidential. This is supported by the felicitous follow-up sentences after the reportative evidential in (1): 'But I don't believe this' or 'But this is not true.' This is in sharp contrast with direct evidentials, such as (3), where the speaker directly witnesses the event. In this case, the speaker has to be committed to the scope proposition, therefore the follow-up sentences 'But I don't believe this' and 'But this is not true' are infelicitous.

(3) I see that a fox kills one of my chickens.

Tavuk-lar-dan birin-i tilki boğ-du.

chicken-PL-ABL one-ACC fox strangle-3SG.PST

'A fox killed one of the chickens (I witnessed).'

\# I don't believe this. $\quad$ \# This is not true. $\quad \checkmark$ I believe this.

Turkish reportative and inferential evidentials differ in their sincerity conditions (Şener 2011): the reportative does not require the speaker to be committed to the scope proposition, while the inferential evidential does. As a result, the inferential evidential in (2) can't be felicitously followed up by sentences denying the truth of the scope proposition. AnderBois (2014) shows that this is a cross-linguistically robust difference between reportative and inferential evidentials.

Turkish also allows "doubling" of the indirect evidential suffix, as in (4). The double evidential in (4) is not compatible with speaker commitment, as evidenced by the infelicity of the follow-up 'I believe this.'

(4) I find one of my chickens dead. I talked to my neighbor who said that the chicken was killed by a fox. I do not trust the neighbor.

I say: I talked to the neighbor,...

Tavuk-lar-dan birin-i tilki boğ-тиş-muş.

chicken-PL-ABL one-ACC fox strangle-3SG.EVID-DUB

'A fox killed one of the chickens (I heard, but I don't believe it).'

\section{$\checkmark$ I don't believe this. $\quad \checkmark$ This is not true. $\quad$ \# I believe this.}

Şener (2011) analyzes (4) as reduplication of the evidential suffix, and argues that the semantic consequence of the reduplication is "an intensified meaning of non-commitment." The goal if this paper is to take a closer look at the double evidential construction, and to present novel morphological and semantic evidence against the reduplication analysis.

The paper is organized the following way: section 2 introduces Turkish indirect evidentials and double evidentials, along with Şener's (2011) reduplication analysis of double evidentials. Section 3 offers evidence against the reduplication analysis and establishes that the second $-m I_{S}$ heads a distinct functional projection. Section 4 concludes and addresses future research.

The Turkish data presented in this paper come from grammaticality judgement questionnaires filled out by four native speaker consultants.

2. General characteristics and previous analysis. In Turkish, indirect evidentiality (reportative or inferential) can be expressed by two very similar-looking yet distinct morphological exponents: $-m I_{s ̧}$ and $-(y) m I_{S} .{ }^{3}$ One of the main arguments for treating these as distinct

\footnotetext{
${ }^{3}$ Capital letters in affixes indicate sound alternation depending on the sounds of the stem. Capital "I" marks fourfold vowel harmony; the vowel can be realized as [i], [1], [u], or [ü]. The suffix-initial glide in - $(y) m I S$ is in parenthesis, because it drops when the stem ends in a consonant.
} 
morphemes is that their meanings are different: while $-\mathrm{mIS}$ always indicates indirect evidentiality and perfect aspect, $-(y) \mathrm{mIS}$ only has indirect evidential meaning without the aspectual component. The suffix $-m I s ̧$ only attaches to verb stems. The form - $(y) m I s ̧$ follows Slot 1 (aspectual) suffixes, as shown in Table 1, and nominal stems. - $(y) m I s ̧$ has a long form in imiş. -(y) $m I s$ can't follow verbal stems as illustrated by the unavailability of the long form imis with

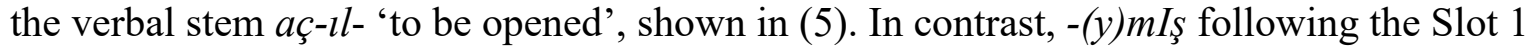
prospective morpheme $-(y) A c A k$, as in (6), can be substituted for the long form imiş

Okul Haziran-da aç-ll-mış / *aç-ıl imiş.

school June-LOC open-PASS-3SG.EVID

'The school was opened in June, (I hear / I infer).'

Okul Haziran-da aç-ıl-acak-mış / aç-ıl-acak imiş.

school June-LOC open-PASS-PROSP-3SG.EVID

'The school is going to get opened in June, (I hear / I infer).'

\begin{tabular}{l|l|l|l} 
Stem & Modals/Inner Aspect & Slot 1 & Slot 2 \\
\hline verb stem & $-(y)$ Abil- & - IIs (prf/evid) & \\
& $-(y)$ Akal- & $-D I$ (dir.evid pst/prf) & \\
& $-(y)$ Iver- & $-(I)$ yor (cont) & $-(y) d I /$ idi (dir.evid pst) \\
& & $-(I / A) r$ (habit) & mIş /imiş (evid) \\
& & $-(y)$ AcAk (prosp) & \\
& & $-m$ AlI (modal) & \\
\hline noun stem & \multicolumn{2}{|c|}{ (not possible) } & \\
\hline
\end{tabular}

Table 1. Turkish functional projections (based on Göksel \& Kerslake (2011: 153))

Double evidentials are possible with both $-m I_{S ̧}$ and $-(y) m I_{S ̧}$, as illustrated in (7). Presumably, it is the morphological similarity between the indirect evidential $-m I s ̧ /-(y) m I s ̧$ and the second - $m I S ̧$ what leads Şener (2011) to analyze the second $-m I S ̧$ as the reduplicated form of the indirect evidential suffix.
Okul Haziran-da aç-ıl-mış-mış
I aç-ıl-acak-mış-mış.
school June-LOC open-PASS-3SG.EVID-DUB / open-PASS-PROSP-3SG.EVID-DUB
'The school was reopened in June (I heard but I don't believe it)/ will be reopened in June (I heard but I don't believe it).'

Despite the morphological similarities, double evidentials have properties that set them apart from "simple" indirect evidentials. For instance, double evidentials are only possible with reportatives, as in (4), but not with inferential evidentials (Şener 2011), shown in (8).

(8) Shortly after I find one my chickens dead, I see a fox, so I think that my chicken was killed by a fox. But then I talk to my neighbor, who tells me that a dog attacked my chicken. I say:

\# Tavuk-lar-dan birin-i tilki boğ-muş-muş. chicken-PL-ABL one-ACC fox strangle-3SG.EVID-DUB

'A fox killed one of the chickens (I inferred but I don't believe it).'

In contrast to simple reportatives, illustrated in (9), double evidentials can't be uttered in out-of-the-blue contexts (also observed by Şener 2011). The double evidential in (4) can only be uttered if the source of information is in the common ground. That is, in the case of (4), 'I talked 
to the neighbor (and she said $p$ )' needs to be in the common ground for the double evidential to be able to uttered felicitously.

(9) What happened?

Tavuk-lar-dan birin-i tilki boğ-muş.

chicken-PL-ABL one-ACC fox strangle-3SG.EVID

'A fox killed one of the chickens (I heard).'

Şener (2011) analyzes the double evidential as morphological reduplication. The reduplication intensifies the lack of speaker commitment expressed by the reportative evidential. Following Inkelas \& Zoll 2005, Şener posits an abstract Reduplication (REDUP) node, which is responsible for the semantic interpretation of morphological reduplication. REDUP encodes that the speaker does not believe that the scope proposition is true. Şener's (2011: 136) formal definition of the meaning of the REDUP node is given in (10).

[[REDUP]]: [ $\lambda \mathrm{p}: \exists \mathrm{w}^{\prime}$ compatible what the speaker believes in $\mathrm{w}$ at $\left.\mathrm{t}: \mathrm{p}\left(\mathrm{w}^{\prime}\right)=0\right]$

Section 3 offers arguments against the reduplication analysis relying on novel morphological and semantic data. These new data leads us to conclude that the second $-m I s ̧$ is distinct from the indirect evidential, and it spells out the head of the Dubitative functional projection.

\section{Double evidentials are not the result of reduplication}

3.1. MORPHOLOGICAL EVIDENCE: INTERVENING MORPHEMES. According to the Morphological Doubling Theory (Inkelas \& Zoll 2005), the base and reduplicated affixes are generated by the morphological component of the grammar in the configuration given in (11). This structure does not allow discontinuous base and reduplicated affixes that are separated by another morpheme, as the intervening morpheme would need to come between the two daughter nodes, resulting in a disallowed structural configuration.

(11) Structure of reduplication in Inkelas \& Zoll's (2005) Morphological Doubling Theory

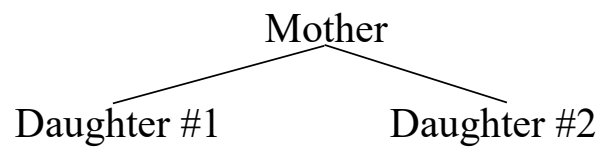

Thus, if Şener's reduplication analysis of the Turkish double evidentials is on the right track, the prediction is that no morpheme can intervene between the base and the reduplicated suffixes. This is, however, not what we find.

Subject agreement suffixes can follow the second $-m I s$, or they may intervene between the indirect evidential and the second $-m I s$. This is shown in (12), where the $1^{\text {st }}$ person singular agreement suffix -Im comes between the two - $m I s ̧$-s.

$$
\begin{aligned}
& \text { Bir çalışan-a hakaret et-miş-im-miş } \quad \text { / et-miş-miş-im. } \\
& \text { a worker-DAT insult LV-EVID-1SG-DUB / LV-EVID-DUB-1SG } \\
& \text { 'I insulted an employee (they say, but I don't believe it)' }
\end{aligned}
$$

If $-m I S ̧-m I S ̧$ was in fact a case of reduplication in Turkish, no other morphemes would be allowed between the base and the reduplicated suffixes. As it is not what we see, we are lead to think that $-m I S ̧-m I s ̧$ does not arise due to reduplication.

3.2. MorPhOLOGICAL EVIDENCE: OTHER TURKIC LANGUAGES. Turkish is not the only Turkic language that has a morphological way to express the lack of speaker commitment towards a 
proposition for which the speaker has indirect evidence. Kazakh, a Kipchak Turkic language spoken mainly in Kazakhstan, also has constructions similar to Turkish double evidentials such as (4). An illustrative example is given in (13), which is quoted from Straughn 2011: 110.
Olar-duy ufag-u
aspan-da bir zer-de
3ogal-up
ket-ipti-mis.
they-GEN plane-3POSS sky-LOC a place-LOC disappear-IP LV-3EVID-DUB
'Their plane disappeared somewhere in the sky (I head but I don't believe it).'

(Kazakh, Straughn 2011: 110)

In Kazakh, indirect evidentials (reportatives and inferentials) are marked by the suffix $-(I) p(t I) .^{4}$ As (13) shows, the lack of speaker commitment is expressed not by repeating $-(I) p(t I)$, but by a completely different suffix $-M I s$, which is etymologically related to Turkish $-m I S$.

The fact that in other Turkic languages the lack of speaker commitment is expressed by a suffix other than the indirect evidential, further strengthens the claim that we are dealing with a distinct functional projection.

3.3. SEMANTIC EVIDENCE: INTRODUCING A NEW INDEXICAL. An additional piece of evidence against the reduplication analysis comes from indexical shift. The Evidential Origo (first introduced by Garrett 2001) is the individual who acquired direct or indirect evidence regarding the scope proposition. In assertions, the Evidential Origo is the speaker, while in informationseeking (non-biased) questions it is the addressee, this latter is called evidential flip (Korotkova 2016, for further discussion on non-flip languages see Bhadra 2020). As discussed by Korotkova (2016) and (Meriçli 2016), in Turkish non-biased questions the Evidential Origo must shift to the addressee, as illustrated by (14).

Okul ne zaman aç-ll-acak-mış?

school what time open-PASS-3SG.PROSP-EVID

'(According to your indirect evidence) When is the school getting reopened?'

* '(According to my indirect evidence) When is the school getting reopened?'

The Evidential Origo shift is summarized in Table 2.

Assertions

Questions

\begin{tabular}{ccc}
\hline $\begin{array}{c}\text { Evidential Origo } \\
=\text { Speaker }\end{array}$ & $\checkmark$ & $X$ \\
$\begin{array}{c}\text { Evidential Origo } \\
=\text { Addressee }\end{array}$ & $X$ & $\checkmark$ \\
\hline
\end{tabular}

Table 2. Evidential Origo in assertions and questions

If the sole function of the second $-m I s ̧$ in double evidential constructions is to reinforce the lack of speaker commitment, the prediction is that the person who is doubtful towards the scope proposition (for ease of exposition I refer to this person as the Evaluator) should always be identical to the person who holds the relevant information (i.e., the Evidential Origo). That is, we would expect the Evaluator to be the speaker in assertions, and the addressee in (non-biased) questions. These predictions are summarized in Table 3.

\footnotetext{
${ }^{4}$ The sounds in parenthesis are dropped in certain environments. The (tI) part of the suffix is dropped if $1^{\text {st }}$ and $2^{\text {nd }}$ person agreement markers attach to the suffix, but it is retained in $3^{\text {rd }}$ person.
} 
Evidential Origo Evaluator

\begin{tabular}{ccc}
\hline $\begin{array}{c}\text { Speaker } \\
\text { (Murat) }\end{array}$ & $X$ & $X$ \\
$\begin{array}{c}\text { Addressee } \\
\text { (Gökçen) }\end{array}$ & $\checkmark$ & $\checkmark$ \\
\hline
\end{tabular}

Table 3. Predictions by the reduplication analysis for non-biased questions

However, this prediction is not borne out. I found that the Evaluator shifts differently from the Evidential Origo in questions. The context in (15) sets up a situation where the addressee (Gökçen) is the Evidential Origo, but the person who doubts the truth of the scope proposition, i.e., the Evaluator, is not the addressee but the speaker (Murat).

(15) Murat has not been going to school for a couple weeks due to the coronavirus. Murat's friend, Gökçen is the neighbor of the school principal. Gökçen thinks the principal is reliable, but Murat thinks the principal is unreliable. Murat knows that Gökçen talked to the principal about schools reopening.

Murat (speaker) calls Gökçen (addressee), and asks this:

Okul ne zaman aç-ıl-acak-muş-mış?

school what time open-PASS-3SG.PROSP-EVID-DUB

'(According to your source that I deem unreliable) When is the school getting reopened?'

In fact, it turns out that the Evaluator can't shift in questions at all. The context in (16) is set up in a way that the addressee is the Evidential Origo and the Evaluator at the same time, but the double evidential question can't be use felicitously in this context.

(16) Murat has not been going to school for a couple weeks due to the coronavirus. Murat's friend, Gökçen is the neighbor of the school principal. Murat knows that Gökçen does not trust the principal. But Murat thinks that the principal is reliable, and believes what he says. Murat knows that Gökçen talked to the principal about schools reopening. Murat (speaker) calls Gökçen (addressee), and asks this:

\# Okul ne zaman aç-ll-acak-mış-mış? school what time open-PASS-3SG.PROSP-EVID-DUB '(According to your source that you deem unreliable) When is the school getting reopened?'

The attested indexical shift patterns with the Evidential Origo and the Evaluator are given in Table 4.

$$
\text { Evidential Origo Evaluator }
$$

\begin{tabular}{ccc}
\hline $\begin{array}{c}\text { Speaker } \\
\text { (Murat) }\end{array}$ & $X$ & $\checkmark$ \\
$\begin{array}{c}\text { Addressee } \\
\text { (Gökçen) }\end{array}$ & $\checkmark$ & $X$ \\
\hline
\end{tabular}

Table 4. Indexical shift in non-biased questions (attested patterns)

As the comparison of the predictions in Table 3 and the attested patterns in Table 4 reveal, the reduplication analysis makes wrong predictions about the Evaluator shift, as the Evaluator does 
not shift in questions. This suggests that the second $-m I s ̧$ should be treated as a completely different category than the indirect evidential $-m I s ̧$.

4. Conclusions and Future directions. The previous section presented morphological and semantic evidence against the reduplication analysis. The presented evidence leads us to conclude that the two $-m I S s$-s in Turkish double evidential constructions are distinct. I propose that the second $-m I s ̧$ spells out a separate syntactic projection I call Dubitative. Thus the table of Turkish functional projections can be amended the following way:

\begin{tabular}{|c|c|c|c|c|}
\hline Stem & $\begin{array}{l}\text { Modals, } \\
\text { Inner } \\
\text { Aspect }\end{array}$ & Slot 1 & Slot 2 & Slot 3 \\
\hline verb stem & $\begin{array}{l}-(y) \text { Abil- } \\
\text {-(y)Akal- } \\
\text {-(y)Iver- }\end{array}$ & $\begin{array}{l}\text {-mIş (prf/evid) } \\
\text {-DI (dir.evid pst/prf) } \\
\text {-(I)yor (cont) } \\
\text {-(I/A)r (habit) } \\
\text {-(y)AcAk (prosp) } \\
\text {-mAlI (modal) } \\
\ldots\end{array}$ & \multirow[t]{2}{*}{$\begin{array}{l}\text {-(y)dI / idi (dir.evid pst) } \\
\text {-(y)mIş / imiş (evid) }\end{array}$} & \multirow[t]{2}{*}{$-m I s ̧(\mathrm{dub})$} \\
\hline noun stem & & ossible) & & \\
\hline
\end{tabular}

Table 5. Turkish functional projections (modified based on Göksel \& Kerslake (2011: 153))

The detailed semantic analysis of the Turkish Dubitative is left for future work, including the analysis of the new indexical, the Evaluator, introduced by the Dubitative head. Furthermore, Bulgarian is known to have a similar double evidential dubitative construction (see e.g., Sauerland \& Schenner 2007). Research underway investigates the similarities and differences of the Bulgarian and Turkish double evidential constructions.

\section{References}

Aikhenvald, Alexandra Y. 2004. Evidentiality. Oxford: Oxford University Press. https://doi.org/10.1093/oxfordhb/9780198759515.013.1.

AnderBois, Scott. 2014. On the exceptional status of reportative evidentials. In Todd Snider, Sarah D’Antonio \& Mia Wiegand (eds.), Semantics and Linguistic Theory (SALT 24), 234-254. Washington, DC: Linguistic Society of America \& Cornell University. https://doi.org/10.3765/salt.v24i0.2424.

Bhadra, Diti. 2020. The semantics of evidential in questions. Journal of Semantics 37. 367-423. https://doi.org/10.1093/jos/ffaa003.

Faller, Martina. 2002. Semantics and pragmatics of evidentials in Cuzco Quechua. Stanford, CA: Stanford University dissertation.

Garrett, Edward. 2001. Evidentiality and assertion in Tibetan. Los Angeles: University of California dissertation.

Göksel, Aslı \& Celia Kerslake. 2011. Turkish: An essential grammar. London \& New York: Routledge. https://doi.org/10.4324/9780203883303.

Inkelas, Sharon \& Cheryl Zoll. 2005. Reduplication: Doubling in morphology. Cambridge: Cambridge University Press. https://doi.org/10.1017/cbo9780511627712.

Izvorski, Roumyana. 1997. The present perfect as an epistemic modal. In Aaron Lawson (ed.), Semantics and Linguistic Theory (SALT 7), 222-239. Washington, DC: Linguistic Society of America \& Cornell University. https://doi.org/10.3765/salt.v0i0.2795. 
Korotkova, Natalia. 2016. Heterogeneity and uniformity in the evidential domain. Los Angeles: University of California dissertation. https://escholarship.org/uc/item/40m5f2f1.

Meriçli, Benjamin S. 2016. Modeling indirect evidence. Santa Cruz, CA: University of California dissertation.

Murray, Sarah E. 2010. Evidentiality and the structure of speech acts. New Brunswick, NJ: Rutgers University disertation .

Murray, Sarah E. 2017. The semantics of evidentials. Oxford: Oxford University Press. https://doi.org/10.1093/oso/9780199681570.001.0001.

Sauerland, Uli \& Mathias Schenner. 2007. Embedded evidentials in Bulgarian. In Estela PuigWaldmuller (ed.), Proceedings of Sinn und Bedeutung 11, 495-509. Barcelona: Universitat Pompeu Fabra.

Şener, Nilüfer. 2011. Semantics and pragmatics of evidentials in Turkish. Storrs, CT: University of Connecticut dissertation.

Straughn, Christopher A. 2011. Evidentiality in Uzbek and Kazakh. Chicago: University of Chicago dissertation. 